\title{
Status, distribution and conservation of Kentish plover Charadrius alexandrinus (Aves, Charadriiformes) in Sicily
}

\author{
Paolo Galasso ${ }^{1 *}$, Giovanni Spinella ${ }^{2}$, Manuel Andrea Zafarana ${ }^{1}$, \\ Antonino Barbera ${ }^{3}$, Andrea Cusmano ${ }^{4}$, Giovanni Cumbo ${ }^{5}$, Davide D’Amico ${ }^{6}$, \\ Dario Grimaldi ${ }^{7}$, Renzo Ientile ${ }^{8}$, Francesco Laspina ${ }^{9}$, Davide Pepi ${ }^{10}$, \\ Antonino Torre ${ }^{11}$, Giancarlo Torre ${ }^{1}$, Salvatore Surdo ${ }^{12}$
}

\begin{abstract}
The Kentish Plover Charadrius alexandrinus is a sensitive species whose national breeding population has been undergoing a sharp decrease, up to $50 \%$, in 2010 compared to the previous decade. Due to the lack of updated data and fragmented knowledge about its current status and distribution in Sicily, a specific and accurate monitoring of this species was carried out during the years 2018 and 2019. About $230 \mathrm{~km}$ of coastline and 64 UTM squares $10 \times 10 \mathrm{~km}$ were investigated during the breeding seasons, and a total of 205-287 pairs have been estimated for the whole region, distributed in 41 UTM squares (including the island of Favignana). Pairs are mainly concentrated in the complex of "Saline di Trapani and Stagnone di Marsala" and along the sandy coast of Gulf of Gela, with a higher abundance along the southeast coast of the region. Breeding population showed a decrease of $18-28 \%$ in number of pairs in comparison to the last estimation of 250-400 pairs reported for the years 2009-2010. After the investigation of $108 \mathrm{~km}$ of coastline and 46 UTM squares, the Sicilian wintering population has been estimated at 376-563 ind., with wintering flocks mainly concentrated in the wetlands of "Mazara del Vallo" and along the coasts of Syracuse and the Gulf of Gela. These updated
\end{abstract}

Stiftung Pro Artenvielfalt $\AA$, Meisenstraße 65, 33607 Bielefeld, Germany.

2 Comitato Nazionale Conservazione Fratino (CNCF), Via S. Giuseppe 12, 90010 Lascari (PA), Italia.

${ }^{3}$ Via Giovanni Prati 28, 91022 Castelvetrano (TP), Italia.

${ }^{4}$ Via Alessio Narbone 52, 90138 Palermo, Italia.

${ }^{5}$ Stazione Ornitologica Aegithalos, Via Aquino Molara 75, 90046 Monreale (PA), Italia.

${ }^{6}$ Via S. Lorenzo 354, 90146 Palermo, Italia.

${ }^{7}$ Via Gaetano Donizetti 51, 95126 Catania, Italia.

${ }^{8}$ Centro Universitario per la Tutela e la Gestione degli Ambienti Naturali e degli Agro-ecosistemi (CUTGANA), Università degli Studi di Catania, Via Santa Sofia 98, 95123 Catania, Italia.

${ }^{9}$ Via Umberto 39, 95025 Aci Sant'Antonio (CT), Italia.

${ }^{10}$ LIPU Sezione Niscemi, Via Angelo Marsiano, 93015 Niscemi (CL), Italia

${ }^{11}$ Via Rio Rosso 24, 98057 Milazzo (ME), Italia.

12 Dipartimento SAAF, Università degli Studi di Palermo, Viale delle Scienze, Edificio 4, 90128 Palermo, Italia.

* Corresponding author: paolo_galasso@hotmail.com

(C) 2021 Paolo Galasso, Giovanni Spinella, Manuel Andrea Zafarana, Antonino Barbera, Andrea Cusmano, Giovanni Cumbo, Davide D'Amico, Dario Grimaldi, Renzo Ientile, Francesco Laspina, Davide Pepi, Antonino Torre, Giancarlo Torre, Salvatore Surdo

Received for publication: 4 June 2021

Accepted for publication: 2 November 2021

Online publication: 9 March 2022 estimates place Sicily as the second most important Italian region for the wintering of this species, just after Sardinia. For the first time, the data collected have made it possible to draw up qualitative-quantitative maps of C. alexandrinus distribution in Sicily, providing an important instrument for the management and planning of specific conservation actions, which should be based on habitat protection and implementation of appropriate artificial ecological niches.

Key words: breeding, distribution map, estimation, Italy, wintering.

Riassunto - Status, distribuzione e conservazione del fratino Charadrius alexandrinus (Aves, Charadriiformes) in Sicilia.

Il fratino Charadrius alexandrinus è una specie sensibile la cui popolazione nazionale sta andando incontro ad un forte declino, fino al $50 \%$ nel 2010 rispetto al decennio precedente. A causa della mancanza di dati aggiornati e della frammentaria conoscenza del suo attuale status e distribuzione in Sicilia, negli anni 2018 e 2019 è stato effettuato un monitoraggio specifico e accurato di questa specie. Durante la stagione riproduttiva sono stati indagati circa $230 \mathrm{~km}$ di costa e 64 quadrati UTM $10 \times 10 \mathrm{~km}$, stimando complessivamente 205-287 coppie nidificanti per l'intera regione, distribuite in 41 quadrati UTM (inclusa l'isola di Favignana). Le coppie erano concentrate principalmente nel complesso delle "Saline di Trapani e dello Stagnone di Marsala" e lungo la costa sabbiosa del Golfo di Gela, con una maggiore abbondanza lungo la costa sud-orientale della regione. La popolazione nidificante ha mostrato una diminuzione del $18-28 \%$ del numero di coppie rispetto all'ultima stima di 250-400 coppie riportata per gli anni 2009-2010. Dopo l'indagine di $108 \mathrm{~km}$ di costa e 46 quadrati UTM, la popolazione siciliana svernante è invece stata stimata in 376-563 individui, con contingenti svernanti concentrati principalmente nelle zone umide di Mazara del Vallo e lungo le coste di Siracusa e del Golfo di Gela. Questa stima aggiornata colloca la Sicilia come seconda regione in ordine di importanza per lo svernamento della specie in Italia, subito dopo la Sardegna. Utilizzando i dati raccolti, per la prima volta sono state prodotte delle mappe quali-quantitative della distribuzione di C. alexandrinus in Sicilia, che rappresentano un importante strumento di gestione e pianificazione $\mathrm{di}$ specifiche azioni di conservazione, che dovrebbero basarsi su un'adeguata protezione degli habitat e sull'implementazione di nicchie ecologiche artificiali appropriate.

Parole chiave: Italia, nidificazione, mappa di distribuzione, stima, svernamento.

\section{INTRODUCTION}

The Kentish Plover Charadrius alexandrinus L. 1758 , is currently evaluated as "Least Concern" (LC), both globally and at European range (BirdLife International, 2021), whereas its trend is considered as slightly decreasing mainly in the northern part of its range (Keller et al., 2020). In Italy, according to the last Red List 
of Italian breeding birds, it is evaluated as "Endangered (EN)" (Gustin et al., 2019), due to the sharp reduction in numbers of the national population, estimated at $-50 \%$ for the years 2000-2010 (Peronace et al., 2012). The Italian breeding population of $C$. alexandrinus was estimated at 1,300-2,000 pairs for the years 2000-2005 (Brichetti \& Fracasso, 2004), at 1,502-1,851 pairs for the years 20092010 , with a variable regional decrease from a minimum of $-20 \%$, up to $-80 \%$ (Biondi \& Pietrelli, 2011), at 1,3011,597 pairs in 2014 (Brichetti \& Fracasso, 2018), while only 579-687 breeding pairs are accounted for the years 2013-2018, according to the last report of the Bird Directive (nature-art12.eionet.europa.eu/article12/summary). The most important Italian regions for the species are Sardinia, with 580-645 pairs, Veneto, with 328-383 pairs, and Sicily, with 250-400 pairs (Biondi \& Pietrelli, 2011).

National wintering population was estimated at 2,737 individuals (ind.) for the years 1991-1995, at 2,402 ind. in 79 different sites for 1996-2000 (Baccetti et al., 2002), at 2,000 ind. in 91 different sites for 2001-2005 and at 1,522 ind. in 83 sites for 2006-2010 (Zenatello et al., 2014). The highest numbers for the years 2009-2010 are reported for Sardinia with 1,387 ind., Veneto with 247 ind., Apulia with 216-719 ind., and Sicily with 200-400 ind. (Biondi \& Pietrelli, 2011).

In Sicily, C. alexandrinus (Fig. 1) is a partially sedentary, breeding, regular migratory, and wintering species (Massa et al., 2021), which performs pre-reproductive migratory movements between mid-March and mid-May, occasionally from mid-February to mid-June, and postreproductive migratory movements from early July to late November, with a peak in late August-early September (Corso, 2005). The Kentish plover breeds exclusively along the coast, with the exception of 3-5 pairs reported only in a few years for "Biviere di Lentini", Syracuse (Ciaccio \& Priolo, 1997). Pairs are distributed more or less uniformly along the coast, with a lower frequency in the northern/north-eastern coast, especially along the Ionian slope of Messina province (Corso, 2005). This plover mostly occurs at in-use or disused saltpans, lagoons, temporary coastal ponds and low lying coastal areas, both sandy and rocky (Ientile, 2011). Up to the 1990s, the Sicilian breeding population was estimated at 500 pairs (Lo

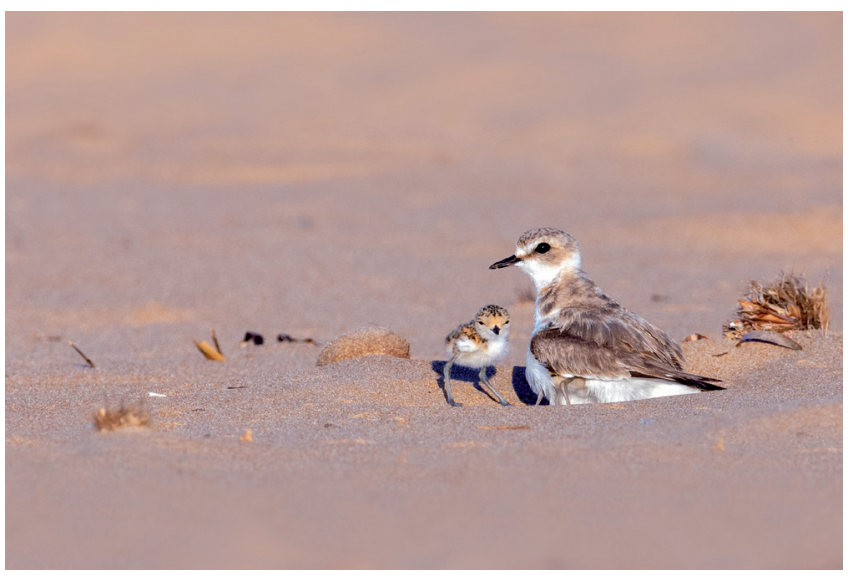

Fig. 1 - Kentish plover female with chicks at "Triscina" beach (Trapani), June 2019. / Femmina di fratino con pulcini sulla spiaggia di "Triscina" (TR), Giugno 2019 (Photo/Foto: A. Barbera).
Valvo et al., 1993) and, subsequently, at 250-400 pairs for the years 2009 and 2010 (Biondi \& Pietrelli, 2011). The wintering population was estimated at a maximum of 100 ind. in the 1980s (Iapichino \& Massa, 1989; Lo Valvo et al., 1993) and at 200-400 ind. for the years 2005-2010 (Ientile \& Corso in Biondi \& Pietrelli, 2011). A ringed bird observed wintering in south-western Sicily in 2011 was found to be regularly breeding in Ukraine.

Even though Sicily represents one of the most important Italian regions for $C$. alexandrinus (Biondi \& Pietrelli, 2011; Zenatello et al., 2014), the regional population has undergone a sharp decrease since 2000, in line with the negative national trend (Ientile, 2011). Indeed, local reductions of $-20 / 30 \%$ are reported for the years $2009-2010$ (Biondi \& Pietrelli, 2011) reaching a maximum of $-70 \%$ (Surdo \& Matteucci, 2016) if compared to the estimates for the years 2000-2005 (Brichetti \& Fracasso, 2004). The main objectives of this survey are to update the current fragmentary knowledge on the trend and distribution of C. alexandrinus in Sicily and to draw up new maps of its breeding and wintering distribution. These maps aim to plan effective conservation strategies based on the analysis of regional vulnerabilities to which this sensitive species is subjected and are inspired by the need to reach a more sustainable coastal management, a goal that can only be reached if both economic and conservation stakeholders (entrepreneurs, local administrations, scientific institutions, conservations panels and volunteers) will cooperate.

\section{MATERIALS AND METHODS}

All the available bibliography about $C$. alexandrinus in Sicily, from the 1970s up to date, was collected and analyzed. Thanks to a network of Sicilian ornithologists and birdwatchers, new data were systematically collected during the years 2018 and 2019, both for the breeding and wintering seasons, covering all the Sicilian coastal provinces, and uploaded into the online database https://www. ornitho.it/. Data on breeding pairs were collected following the instructions of National Committee for the Conservation of Kentish Plover (CNCF - Comitato Nazionale Conservazione Fratino), extending the monitoring period from the beginning of May to June. All the most suitable stretches of coast were selected covering every Sicilian province and standardized coastal transects have been walked following the shoreline (Bibby et al., 2000), always with good weather conditions and no wind, trying to contact adults, pairs, chicks and nests. In addition, the most important and historical breeding sites were monitored as well (e.g. Saline di Trapani and Stagnone di Marsala, Sicilian southeastern swamp lakes complex, etc.). Following the Italian Breeding Bird Atlas instructions (Meschini \& Frugis, 1993; www.ornitho.it), every record was related to an "Atlas code", which categorizes the breeding as "possible" (codes 1-3), "probable" (codes 4-10) or "certain" (codes 11-19). If the species was not recorded, the "absence datum" was recorded as well (code 99). For each individual or nest contacted, geographic coordinates were recorded. On a total of about $1,170 \mathrm{~km}$ of Sicilian coastline and 92 UTM coastal squares $(10 \times 10 \mathrm{~km}), 230 \mathrm{~km}$ and 64 different squares were covered and monitored, including 
the minor islands of Salina, Ustica, Favignana, Pantelleria, Lampedusa and Linosa. Every UTM square was investigated at least once, both for the year 2018 and 2019. If pairs or nests were found, the monitoring was repeated at least once again in the following days. For wintering, the counts recorded for the Italian national waterbird census (Serra et al., 1997; Baccetti et al., 2002; Zenatello et al., 2014) were used. Again, after selecting the most interesting and suitable stretches of coastline in each province, transects were walked along the shoreline, in January 2018 and 2019, recording all the ind. contacted. About $108 \mathrm{~km}$ of coastline and 46 UTM squares $(10 \times 10 \mathrm{~km})$ were monitored in total for the winters 2018 and 2019.

\section{RESULTS}

The results of our field survey allowed us to estimate 205 and 287 breeding pairs in Sicily for the years 2018 and 2019 , respectively. Breeding pairs were found in 41 different UTM squares out of 64 squares investigated (64\%). The recent survey adds 9 new squares, including Favignana Island, to the species distribution and registers the loss of 11 squares compared to the previous distribution map (Fig. 2).

The breeding population is mainly concentrated in the areas of "Saline di Trapani e Marsala" and "Capo Feto" and, despite the numerous sources of disturbance, along the Gulf of Gela (Fig. 3), accounting respectively for about $21-28 \%$ and $12-16 \%$ of the total regional population.

The Sicilian wintering population is estimated at 376563 ind., about $41-88 \%$ more abundant if compared to the

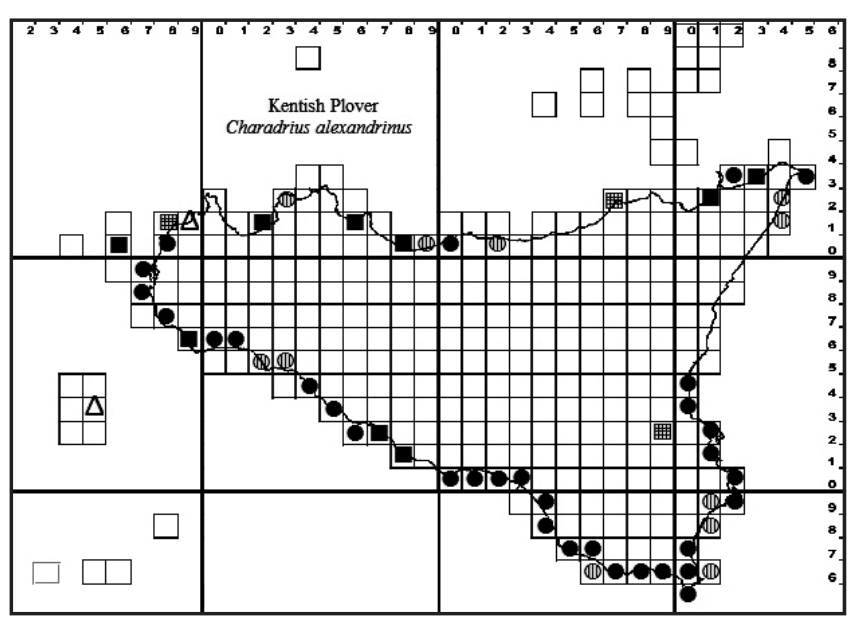

Fig. 2 - Past and present distribution of the Kentish Plover in Sicily. / Distribuzione passata e presente del fratino in Sicilia.

曲 Recorded in earlier atlases (Massa, 1985; Lo Valvo et al., 1993), but not confirmed during the present study. / Rilevato in atlanti precedenti (Massa, 1985; Lo Valvo et al., 1993), ma non confermato da questo studio. $\triangle$ Unpublished records not reported in earlier atlases (Massa, 1985; Lo Valvo et al., 1993; AA.VV., 2008) and not confirmed during the present study. / Dati non pubblicati nei precedenti atlanti (Massa, 1985; Lo Valvo et al., 1993; AA.VV., 2008) e non confermati da questo studio. (1D Presence recorded in AA.VV. (2008), but not confirmed during the present study. / Presenza rilevata in AA.VV. (2008), ma non confermata da questo studio.

- Presence recorded in AA.VV. (2008) and confirmed during the present study / Rilevato in AA.VV. (2008) e confermato in questo studio.

- New record in comparison to the last atlas (2008). / Nuova presenza rispetto all'ultimo atlante (2008). most recent previous estimate of 200-400 ind. for the years 2009 and 2010 (Ientile \& Corso in Biondi \& Pietrelli, 2011). This result is probably the consequence of the much more intensive field effort carried out during this study in comparison to the past. This updated estimate places Sicily as the second most important wintering region for the species in Italy, just after Sardinia. The most important wintering sites are represented by the beach of "Capo Feto" (Trapani), where flocks up to 70 ind. where observed, the mouth of "River Platani" (Agrigento), the complex of "Sicilian south-eastern swamp lakes", the nearby beaches and the nature reserve of "Vendicari" (Syracuse), the rocky coast of "Penisola Maddalena", the area of "Marina di Priolo", the nature reserve of "Saline di Priolo" and "Penisola Magnisi" (Syracuse) and the sandy coast of the Gulf of Catania (Fig. 4).

Since the investigated provinces show peculiar environmental features, they are treated separately.

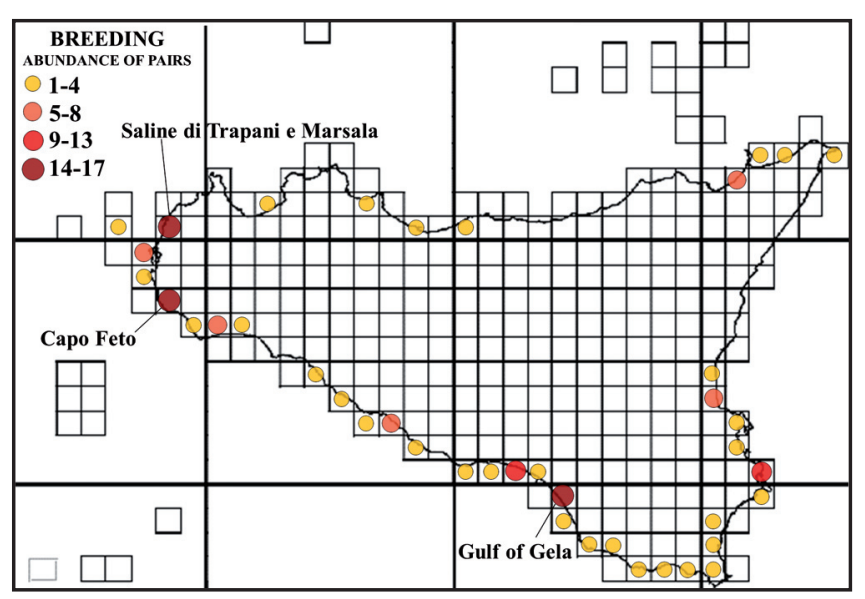

Fig. 3 - Qualitative-quantitative distribution of Kentish plover breeding pairs along the Sicilian coast. Maximum concentrations of pairs were in the areas of "Saline di Trapani e Marsala", "Capo Feto" and along the sandy coast of the Gulf of Gela. / Distribuzione quali-quantitativa delle coppie nidificanti di fratino lungo la costa siciliana. Le massime concentrazioni di coppie si sono registrate nelle aree di "Saline di Trapani e Marsala", "Capo Feto" e lungo la costa sabbiosa del Golfo di Gela.

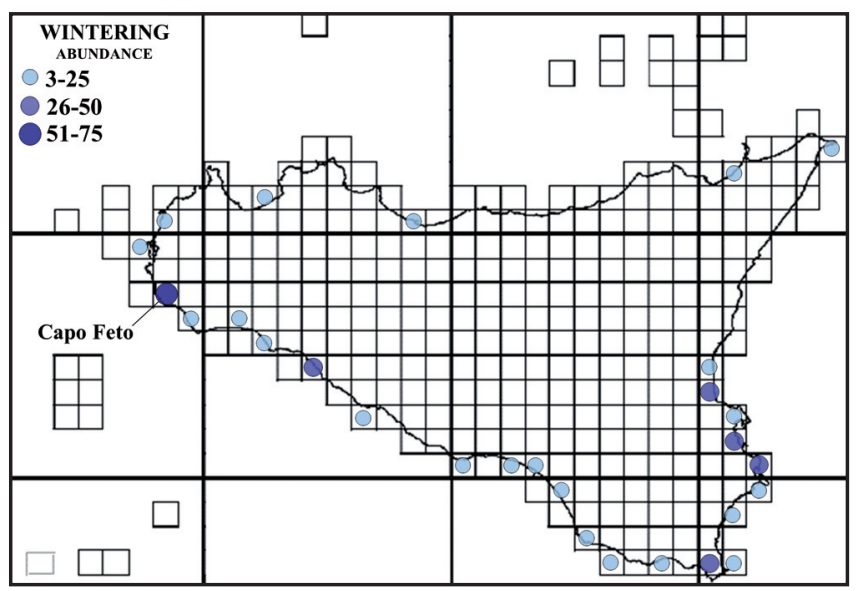

Fig. 4 - Qualitative-quantitative distribution of wintering Kentish plovers along the Sicilian coast. The maximum concentration of birds in a single observation was recorded in the area of "Capo Feto", with a flock of 70 ind. / Distribuzione quali-quantitativa degli individui svernanti di fratino lungo la costa siciliana. La massima concentrazione in una singola osservazione è stata registrata nella zona di "Capo Feto", con un gruppo di 70 ind. 


\section{Trapani province}

The coastline of Trapani province extends for about $200 \mathrm{~km}$ (318 including minor islands), being characterised by sandy beaches south of Trapani and by rocky coasts to the north. It also includes the saltpans complex of "Saline di Trapani e Marsala" that extends for more than 1,200 ha. In the past, this area represented the most important historical Sicilian site for C. alexandrinus, hosting from 118 breeding pairs (Massa, 1977), up to $120-200$ pairs (Corso, 2005). However, only 27 pairs were breeding in 2016 (Surdo \& Matteucci, 2016) and 4 of them, recorded in "Salina Genna" (Surdo et al., 2017), did not nest there in the following years.

Breeding: 54-67 pairs were estimated for the years 2018-19 for the whole province. These were mainly concentrated in "Saline di Trapani and Marsala" (Fig. 5) with 23 pairs, along the beach of "Capo Feto" (Fig. 6) with 7 pairs, in "Laguna di Tonnarella" with 6-8 pairs, and at the mouth of River Belice with 3-5 pairs. Other important locations are "Campobello di Mazara" with 2-4 pairs and "Punta dell'Alga" with 2-4 pairs, as well. Concerning the minor islands, the 1-3 pairs reported for Favignana in 2014 (Massa et al., 2015) were again recorded in the years

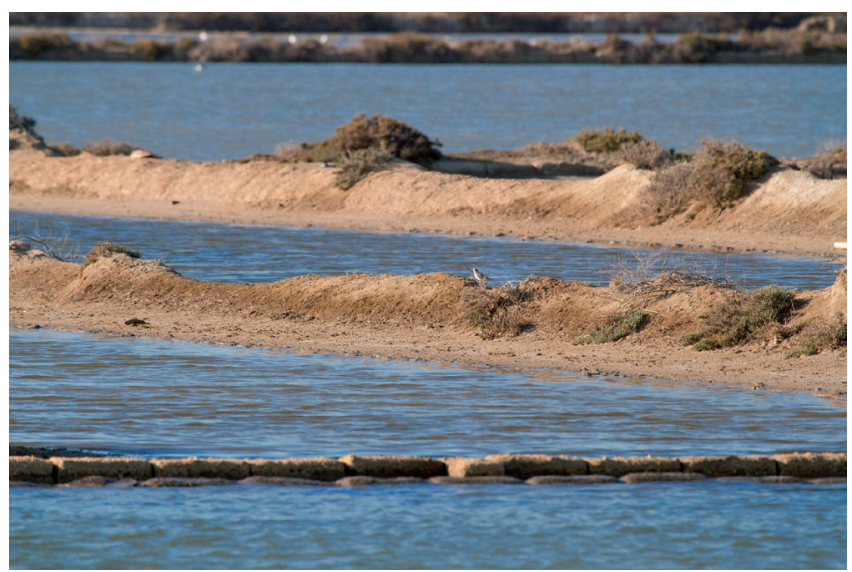

Fig. 5 - Typical breeding habitat of the Kentish plover in "Saline di Trapani". / Tipico habitat riproduttivo del fratino nel sito "Saline di Trapani". (Photo / Foto: G. Spinella).

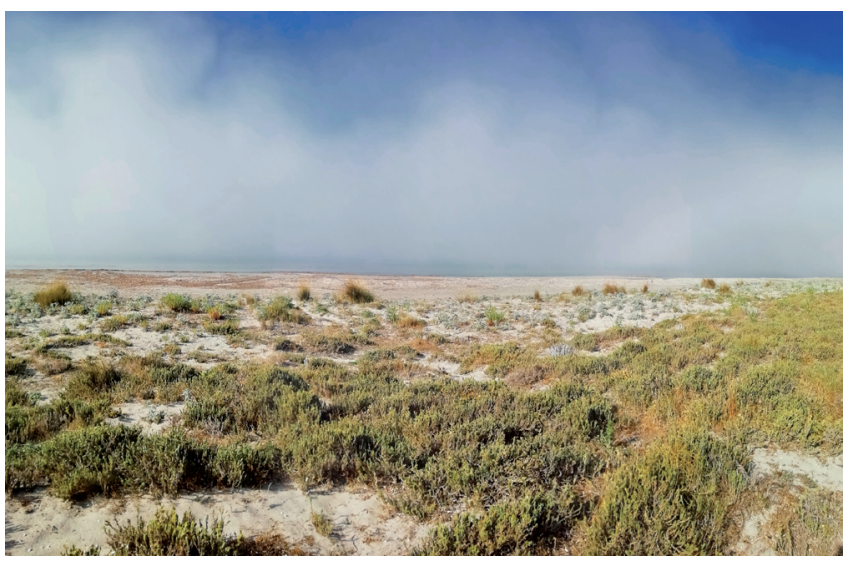

Fig. 6 - The beach of "Capo Feto", one of the most important breeding and wintering sites for the Kentish plover in Sicily. / La spiaggia di "Capo Feto", uno dei più importanti siti di riproduzione e svernamento del fratino in Sicilia (Photo / Foto: A. Barbera).
2018-19. On the other hand, the breeding record for Pantelleria reported by Moltoni (1973), was not confirmed in subsequent years (Massa 1985; Lo Valvo et al., 1993; AA. VV., 2008); even if an individual performing the "broken wing display" was observed in 2016 at the location of "Arenella" (Piero Ferrandes, pers. comm.), no pairs have been recorded for the years 2018-19 (triangle symbol in Fig. 2). The Kentish Plover was also reported as breeding on the islet of "Colombaia", located in front of the port of Trapani (Massa, 1977), altough, despite several inspection from 2015 to 2019, it has not been contacted any more. A breeding pair reported for the year 2000 in Valderice, was no more recorded as well, probably due to excessive anthropic disturbance at the "Forgia beach" over the last twenty years (triangle symbol in Fig.2).

Wintering: the total wintering population of Trapani province is estimated at 95-130 ind., mainly concentrated in the area of "Mazara del Vallo", with records of 50-70 ind. The area is listed as "site of national interest" for the wintering of C. alexandrinus (Zenatello et al., 2014) and its relevance has been already reported for the years 201116 , with records up to 54 ind. in "Laguna di Tonnarella" (Surdo \& Barbera, 2016). Another important wintering site is Marsala, with flocks of 15-20 ind. recorded. Only 17-20 ind. were observed in "Saline di Trapani", confirming the sharp negative trend of the species in this area (Surdo, 2016). Even if it was considered in the past as a "national important area", with records of 120-145 ind. for the years 1999-2000 (Baccetti et al., 2002), it is currently no longer considered as a "site of national interest" for the International Waterbird Census (Zenatello et al., 2014).

Suggested priority conservation measures: sustainable management of water levels in the "Saline di Trapani e Marsala" saltpans; fencing of part of the saltpans to prevent predation and disturbance by stray dogs; forbidding the access of motor vehicles to the beach of "Capo Feto" and to the mouth of "River Belice" area; restoration of the dune system along "Triscina" beach.

\section{Palermo province}

The coastline of the Palermo province extends for about $160 \mathrm{~km}$. The nature of the coast is increasingly sandy moving westward, while it shows gravel and narrow beaches alternate to rocky cliffs moving eastward. Although it seems to offer many suitable breeding sites (e.g. locality of "Acqua dei Corsari”, mouths of the rivers Pollina, Imera Settentrionale, Torto, San Leonardo, Eleuterio, Oreto, Nocella and Jato) this coast is heavily disturbed and urbanised, all conditions that hinder nesting.

Breeding: 15-20 pairs were estimated for the whole province in the years 2018-19. Even though Termini Imerese is characterised by a poor quality of the environment due to pollution, illegal dumps and a large industrial site, some artificial coastal pools along a stretch of coast $4 \mathrm{~km}$ in length have been exploited for breeding. These pools are surrounded by a substrate of compact sand mixed to gravel and pebbles and enclosed by a breakwater barrier to the north and a road to the south (Fig. 7), which limit anthropic disturbance; here, 3-4 


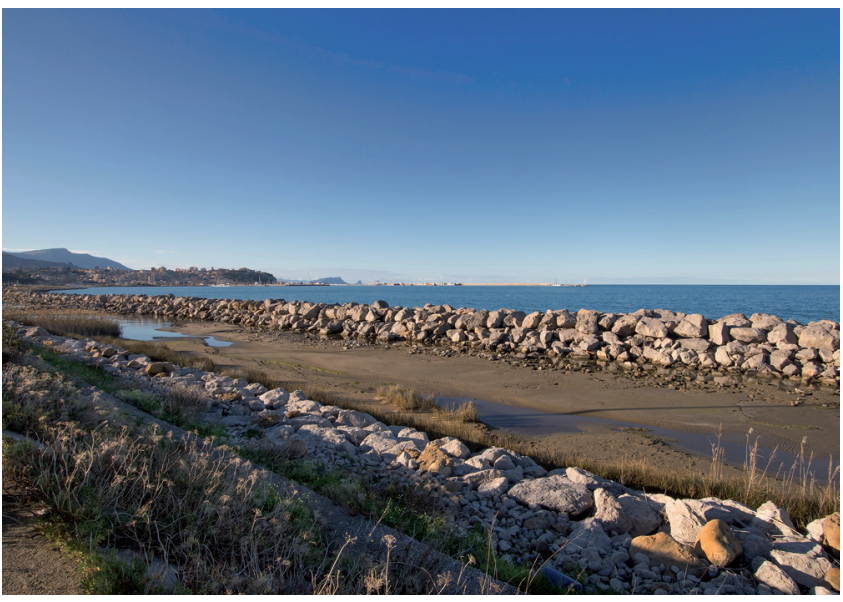

Fig. 7 - Termini Imerese: artificial habitat used by Kentish plover for breeding. / Termini Imerese: habitat artificiale usato dal fratino per la riproduzione (Photo / Foto: G. Spinella).

pairs were regularly recorded in the years 2015-2019. The sandy coast between "Campofelice di Roccella" and "Lascari", which hosted 3-4 pairs as well, is instead characterised by embryo dunes with pioneer vegetation including Achillea maritima (L.) Ehrend. \& Y.P. Guo, Pancratium maritimum L., Eryngium maritimum L., Echinophora spinosa L. and Calamagrostis arenaria (L.) Roth. This stretch of coast is interested by the presence of buildings that hinder the proper development of the dune system and it is affected by various anthropic interferences, such as trampling and sun-bathers, presence of stray cats and, secondly, of mechanical cleaning of the beaches and off-road vehicles. A further breeding pair was found near "Balestrate".

Wintering: about $15-20$ wintering ind. were estimated for the Palermo province; these were mainly observed in "Termini Imerese" with flocks of 11-12 ind., in the same habitat used for breeding. Smaller groups of 3 ind. were also observed in "Balestrate" highlighting the suitability of this stretch of coast.

Suggested conservation measures: fencing and banning of angling at the breeding site of "Termini Imerese"; creation of artificial pools in coastal stretches with similar features. In the stretch of beach between "Buonfornello" and "Lascari", the embryonic dunes should be delimited to avoid crossing and trampling, while access to the beach should be reduced and channelled towards a few obligatory passages with wooden walkways.

\section{Messina province}

Messina has the longest coastline of the region, with a total of $218 \mathrm{~km}$, crossed by many freshwater streams and narrow alluvial plains. The consequence of the high anthropisation of the coastline is the sharp reduction of coastal natural habitats, represented by an alternation of gravel beaches and rocky coasts and cliffs.

Breeding: the about $25-40$ breeding pairs estimated for 2018-19, were exclusively concentrated along the Tyrrhenian slope, in the area of the Gulf of Patti: 7-8 pairs bred between "Barcellona Pozzo di Gotto" and Rometta,

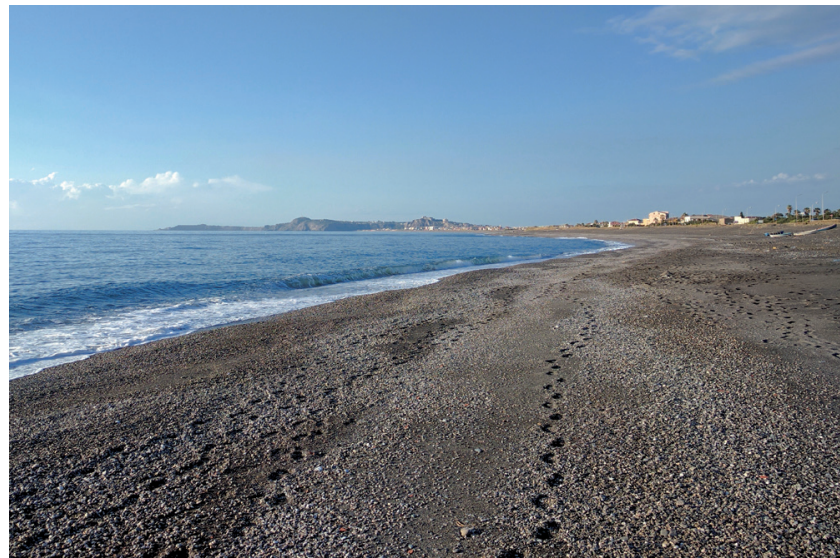

Fig. 8 - A typical gravel beach in Messina province near the mouth of "Torrente Mela", Milazzo. / Una tipica spiaggia di ghiaia nella provincia di Messina vicino alla foce del "Torrente Mela", Milazzo (Photo / Roto: A. Torre)

mainly at the mouth of "Torrente Mela" (Milazzo: Fig. 8). A total of 3-4 pairs were also found along the sandy beach of "Mortelle", near Messina, characterized by an environmentally valuable dune system and related psammophilous vegetation, with Calamagrostis arenaria (L.) and a well-developed vegetation of chamaephytes and hemicryptophytes, almost vanished in the remaining stretches of coast of the province. In the last years, the breeding pairs of Patti Gulf remained stable, despite the heavy disturbance mainly caused by intense tourist activities, beach cleaning, presence of dogs and mechanical vehicles, as well as coastal erosion. The same threats are very frequent and impactful along the coastline of the Ionian slope, which is the poorest stretch of coast of Sicily in terms of the presence of $C$. alexandrinus, as it has already reported by Corso (2005). Even though the species was never observed there during the present survey, the estimate was set at 0-5 pairs based on data from previous years and the amount of suitable habitat along the $70 \mathrm{~km}$ stretch of coast between "Giardini Naxos" and "Torre Faro". Competition with breeding pairs of the little ringed plover $(C$. dubius) recorded by Biondi et al. (2000) and Pietrelli \& Biondi (2009) in the most suitable sites of Ionian coast (mouths of "River Alcantara", "Torrente Agrò", "Torrente Savoca", "Torrente Pagliara", "Fiumedinisi"), could be one of the causes of the total absence of $C$. alexandrinus in this part of the region.

Wintering: 35-50 ind. were estimated for the whole province. The most important wintering site is currently represented by the mouth of "Torrente Mela", with records of 15-20 ind. per winter regularly observed over the years 2015-2019. For the same area, post-reproductive flocks of 35 ind. have been observed from late August to early November. Flocks of 10-20 ind. were also observed along the "Mortelle" beach, as already reported by Baccetti et al. (2002), for "Terme Vigliatore", at the mouth of "Torrente Patrì", and near "Marinello".

Suggested priority conservation measures: no access to motor vehicles and stop of angling near the mouths of the main water courses, especially "River Alcantara", "Torrente Agrò", "Fiumedinisi" and "Torrente Mela". 


\section{Catania province}

The province coastline extends for about $70 \mathrm{~km}$, including $20 \mathrm{~km}$ of sandy beach in the southern part of the Gulf of Catania and about $27 \mathrm{~km}$ of volcanic cliffs and similar unsuitable habitats between the city of Catania and "Riposto". From "Riposto" up to the northern end of the Catania province, near the mouth of "River Alcantara", gravel beaches are exclusively present.

Breeding: 8-13 breeding pairs, found exclusively along the sandy beach of the Gulf of Catania, were estimated for the whole province for the years 2018-19 (Fig. 9); these include 3-4 pairs breeding at the mouth of "River S. Leonardo" and 1-2 pairs breeding at "Salatelle", a system of temporary backdune ponds. Breeding data collected in the area of "River Simeto mouth" are in line with the sharp decline recently reported, from 15 pairs estimated in the 1990s (Ciaccio \& Priolo, 1997) to only 2 pairs for the years 2018-2019 (Zafarana et al., 2019). The whole sandy beach of the Gulf of Catania is deeply anthropized and disturbed, regularly frequented by stray dogs, off-road bikers and anglers, and subjected to mechanical beach cleaning both during the spring/summer, and in late winter. Most of the coast, starting from the "River Simeto mouth", is subject to heavy erosion and the dune vegetation has almost totally disappeared.

Wintering: 29-31 ind. were recorded in the years 2018-19 for this province, mainly at the mouths of "Canale Arci" and "River S. Leonardo" (Galasso et al., 2021). Despite the fact that the mouth of "River Simeto" was considered one of the most important breeding sites for the Kentish plover in Sicily, with up to 120-150 wintering ind. reported for the period 1990-2004 (Baccetti et al., 2002), the species was never recorded as wintering in this site for the period 2011-2020 (Galasso et al., 2021).

Suggested priority conservation measures: fencing of the mouth of "Torrente Acquicella" and promoting the development of its embryo dunes and related vegetation; fencing of the area of "Salatelle"; stop to angling and motor vehicle access to the beach near the mouths of "River Simeto " and "River S. Leonardo".

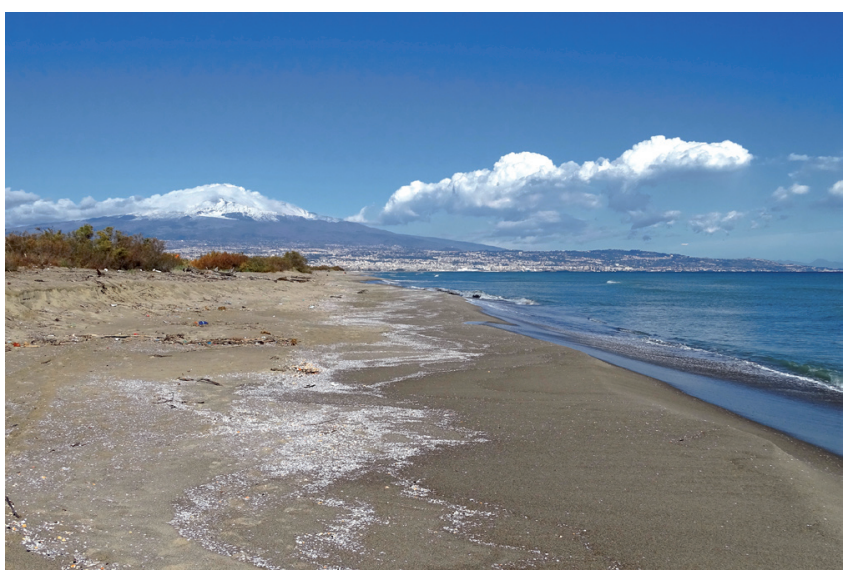

Fig. 9 - Typical view of the sandy shore of the Gulf of Catania, with Mount Etna in the background. / Veduta tipica del litorale sabbioso del Golfo di Catania, con l'Etna sullo sfondo (Photo / Foto: D. Grimaldi).

\section{Syracuse province}

The Syracuse province coastline extends for about 175 $\mathrm{km}$ and includes a wide variety of environments, such as rocky and sandy coasts, cliffs, former saltpans and backdune ponds.

Breeding: the species, has been estimated at 30-40 pairs for the years 2018-19, with 12-15 pairs mainly concentrated in the nature reserve of "Saline di Priolo", the nearby sandy beaches and the "Penisola Magnisi". The number of pairs increased after the construction of artificial islands in "Saline di Priolo" (Cilea \& Iapichino, 2011), though the same authors noticed the negative interaction with the black-winged stilt Himantopus himantopus.

Other important breeding sites are the nature reserve of "Vendicari", with 3-5 pairs (2-3 pairs along the sandy shoreline and 1-2 breeding on the facing small islet of "Isola di Vendicari") and the rocky coast of "Penisola Maddalena" (Fig. 10) with 3-5 pairs. This probably represents the most important rocky habitat for the Kentish plover in Sicily. We report a sharp decrease in the number of pairs at the former saltpans of Syracuse where, due to the strong erosion of the coast and the consequent habitat loss, only 1-2 pairs were recorded in 2018-19. When the saltworks were active (Baglieri, 1972), this was the site with the highest density of pairs in the Syracuse province (Iapichino in Massa, 1985). Over the last twenty years, the population of the former saltpans of Augusta had a strong decline as well, with only 2-3 pairs recorded for 2018-19, despite Ientile (2001) reported a variable number of 3-10 pairs.

Wintering: as for the Trapani province, until 20 years ago large groups of wintering ind. were regularly reported for different locations in the Syracuse province: 150 ind. for the nature reserve "Saline di Priolo" in 2001 and 2003; 90-130 ind. for Avola and Noto beaches, including the nature reserve "Vendicari" and "Saline di Morghella" in 2004 (Corso, 2005). In total, 60-140 wintering ind. were instead estimated for the years 2018-2019. These were mainly congregated in the environmental complex including the nature reserve "Saline di Priolo", the nearby beaches and "Penisola Magnisi", where flocks of 20-30

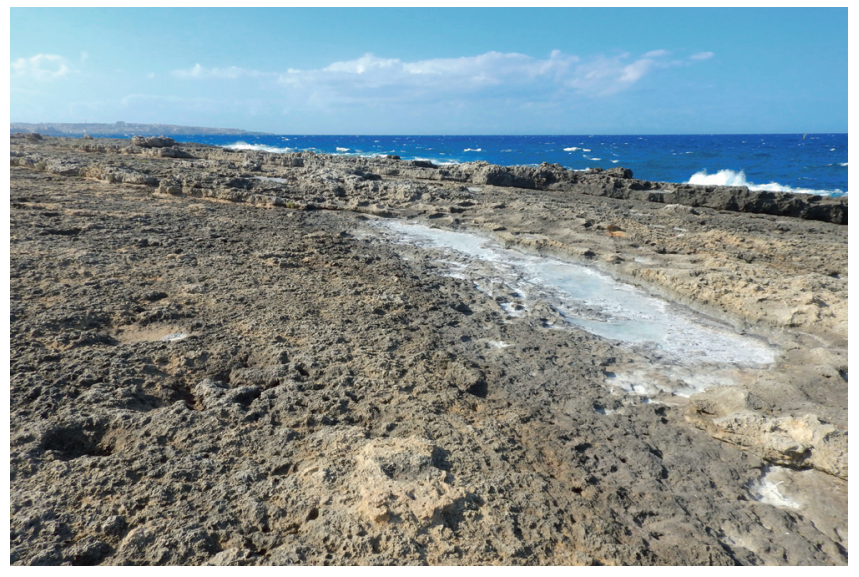

Fig. 10 - Massolivieri, Syracuse: the rocky coast of Penisola Maddalena, a breeding and wintering site used by the Kentish plover. / Massolivieri, Siracusa: la costa rocciosa di Penisola Maddalena, sito di riproduzione e svernamento utilizzato dal fratino (Photo / Foto: R. Ientile). 
ind. were recorded, in the nature reserve of "Vendicari", with 10-20 ind., and in the complex of "Sicilian southern swamp lakes" and nearby beaches, with 15-25 ind.

Suggested priority conservation measures: fencing of the former saltpans of "Saline di Augusta"; fencing and forbidding the access to the mouth of "River Ciane"; preventing livestock grazing at "Penisola Magnisi"; stopping the access to some stretches of beach from April to June between "Calabernardo" and the nature reserve "Vendicari”.

\section{Ragusa province}

The coast of Ragusa province, which extends for about $80 \mathrm{~km}$, still keeps high value stretches of sandy coast, with embryo and primary dune systems that still hold a wellpreserved vegetation including Cakile maritima Scop., Juniperus oxycedrus L., Ephedra fragilis Desf. and Calamagrostis arenaria (L.).

Breeding: the 21-25 pairs estimated for the years 201819 were concentrated mainly along the sandy coast between "Pozzallo" and "Ispica" that includes the swampy lake of Pantano Longarini and its mouth, for a total of 7-8 pairs. The area of "Sicilian southeastern swamp lakes", located between Ispica (Ragusa) and Pachino (Syracuse) and including Pantano Longarini, was considered in the past the second most important area of Sicily for the breeding of the Kentish plover, for which up to 40-70 breeding pairs are reported (Corso, 2005). Other important sites are the beach of "Maganuco", with 2 pairs, the beach of "Sampieri" (Fig. 11) with 2-3 pairs, and the beach of "Randello", with 3-4 pairs. In all these locations, the dune system and its vegetation are still well preserved.

Wintering: about 50-60 wintering ind. were estimated for the whole province of Ragusa, of which 15-20 regularly observed at the mouth of "Pantano Longarini", 1820 along the beach of "Donnalucata" (Carlo Cappuzzello $\&$ Egle Gambino, pers. comm.) and 13-15 along the beach

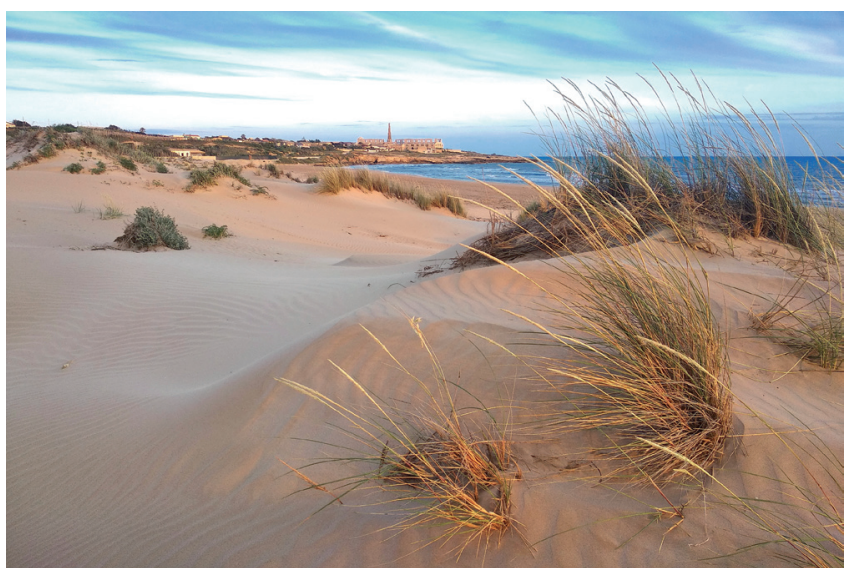

Fig. 11 - The beach of "Sampieri", Ragusa: a valuable sandy coast characterized by primary and embryo dunes with vegetation including Calamagrostis arenaria (L.) and Ephedra fragilis Desf. / La spiaggia di "Sampieri", Ragusa: un pregevole litorale sabbioso caratterizzato da dune primarie ed embrionali con una vegetazione che comprende Calamagrostis arenaria (L.) ed Ephedra fragilis Desf. (Photo / Foto: P. Galasso). of "Randello". At "Pantano Longarini", from 30 up to 52 ind. were also recorded during post-breeding migration, from mid to late November 2017 and 2020.

Suggested priority conservation measures: stopping motor vehicle access to the beaches of "Maganuco", "Porto Ulisse" and "Granelli", and most importantly to the mouth of "Pantano Longarini". Building of wooden walkways to reach the shoreline and avoid to cross the dunes at the beaches of "Sampieri" and "Santa Maria del Focallo". Fencing of the dunes in the same localities is highly recommended.

\section{Caltanissetta province}

The only coastal habitat of this province is found in the Gulf of Gela, an important area between the beach of "Randello" (on the border with the Ragusa province) and the east side of the port of Licata (on the border with the Agrigento province), for which 40-50 pairs were reported in the past years (Rannisi in Casamento et al., 2004).

Breeding: about 30-37 pairs were estimated for the years 2018-19 along the $60 \mathrm{~km}$ of sandy beach of coastline of the Gulf of Gela, especially close to the mouths of "River Dirillo" and "Roccazzelle" (Fig. 12). Despite house building, tourist resorts, greenhouses and beach facilities, some stretches of coast have well-preserved naturalistic peculiarities of international importance (e.g. rare and endemic psammophilous plant species living on relict dunes). The Kentish plover has instead disappeared along the eastern coastal stretch of the Gulf of Gela ("Bulala" beach), which is dominated by the industrial pole and characterised by intensive agricultural activities almost reaching to the shoreline. Although stable in the last decade, the species has decreased in comparison to the $1980 \mathrm{~s}$, when the breeding population reached 100 pairs/year (Giudice in Zafarana, 2017): for this reason, a colour-coded map showing the variation in the intensity of threats to the Kentish plover has been drawn in order to take appropriate conservation measures (Raffa et al., 2018).

Wintering: an estimate of 35-50 wintering ind. for the years 2018-19 for the whole Gulf of Gela, is in line with

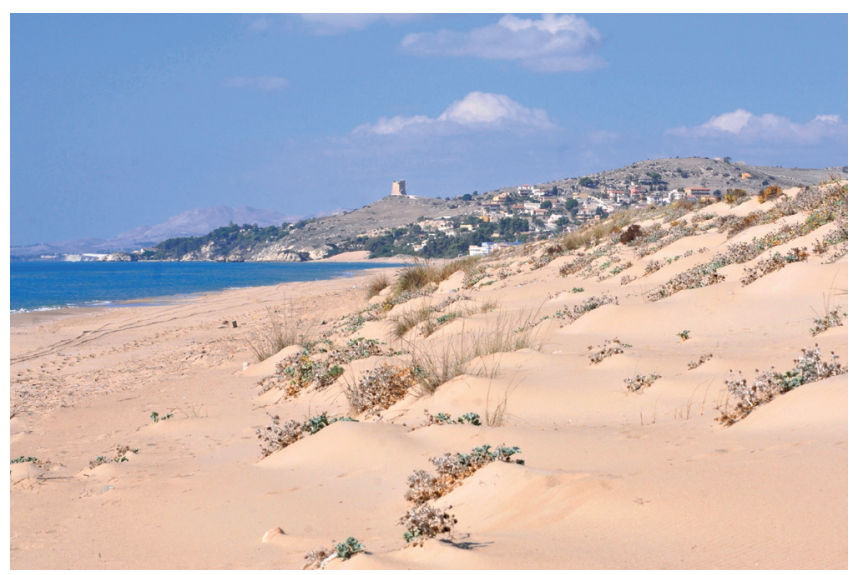

Fig. 12 - Roccazzelle beach, Gela: sandy coast with "Torre Manfria" on the background. / Spiaggia di Roccazzelle, Gela: costa sabbiosa con "Torre Manfria" sullo sfondo (Photo / Foto: M. Zafarana). 
the estimate reported for the years 2011-2016 (42 ind./ year, range: 37-46, Zafarana, 2017).

Suggested priority conservation measures: reclamation of waste at the mouth of "River Dirillo" and removal of hazardous/special waste, fishing lines and hooks, ropes and residual waste from greenhouse agriculture; regulation of kitesurfing at the "Manfria" beach; construction of wooden walkways to reach the shoreline without crossing the dunes on the beach between "Poggio Arena" and the mouth of "River Comunelli".

\section{Agrigento province}

The coastline of this province extends for about $145 \mathrm{~km}$, from "Porto Palo" to the east side of "Licata", including wide sandy beaches that alternate to jagged rocky coasts.

Breeding: about $22-45$ breeding pairs were estimated, located mainly near the mouth of freshwater streams: 4 pairs were recorded at the mouth of "River Platani", 2-3 pairs along the beach of "Siculiana Marina" (Fig. 13), 2-3 pairs at the mouth of "River Naro", 3-4 pairs between "Cannatello" and "Punta Bianca", along the beach of "Cipolluzze". Even though the area is heavily disturbed by tourists, 1-2 pairs were also found in the southeastern tip of "Scala dei Turchi", near "Punta Grande". Agrigento province still offers interesting and well-preserved beaches and stretches of coast suitable to the breeding of the species (e.g. the beach of "Siculiana Marina" and the nature reserve of "Torre Salsa"), but the strong and constant tourist pressure compromised most of them, confining the remaining breeding pairs to poorly accessible areas and river mouths.

Wintering: 57-72 wintering ind. were estimated, mainly concentratedatthemouth of "RiverPlatanil"(23-28ind.:Salvo Grenci \& Ciro Amata, pers. comm.), along the beach between "Porto Empedocle" and "Zingarello", (15-20 ind.: Salvo Grenci, pers. comm.), and between "Porto Palo" and "Menfi" (8-10 ind.); smaller groups of 3-4 ind. were regularly recorded in the port of Sciacca (Gaspare Indelicato, pers. comm.).

Suggested priority conservation measures: we recommend fencing and limiting access to the mouth of the "river Platani" and the "river Naro", at least from April to June. We strongly suggest installing wooden walkways to reach the shoreline in order to avoid crossing the dunes;

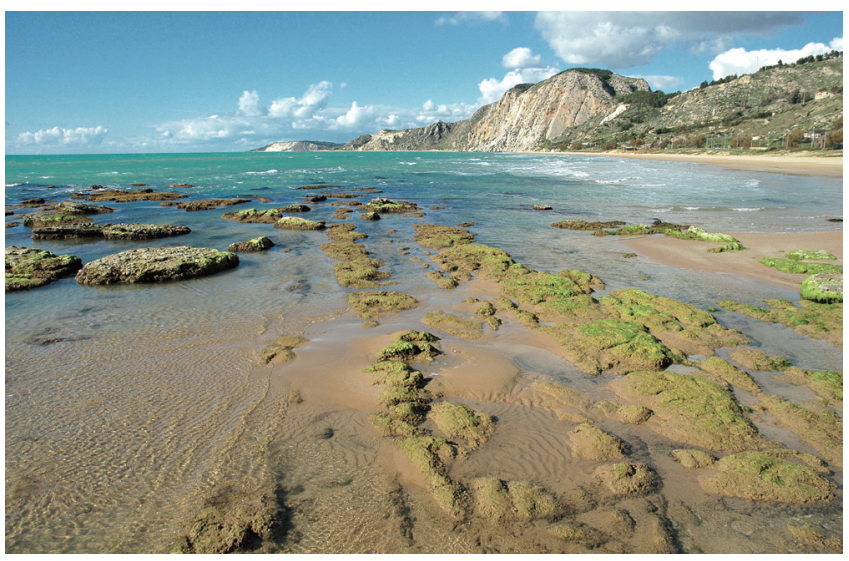

Fig. 13 - The coastline of Siculiana Marina, Agrigento. / La costa di Siculiana Marina, Agrigento. (Photo / Foto: R. Ientile). horse riding should be regulated and restricted along the beach, especially in the "Porto Empodocle" area.

\section{Other minor islands}

Excluding the already mentioned islands of Favignana and Pantelleria, the islands of Linosa, Lampedusa, Ustica and Salina were totally or partially investigated during the breeding season 2018-19 as well, but without success in recording evidence of possible breeding, as recently reported from other authors (Massa et al., 2015).

Table 1 summarizes the breeding and wintering records for each province investigated.

\section{DISCUSSION}

A regional decrease of $C$. alexandrinus of about 18$28 \%$ for the period $2010-2020$ can be definitively confirmed, in comparison to the last estimate of 250-400 pairs for the years 2009 and 2010 (Biondi \& Pietrelli, 2011). It is evident that presence and abundance of $C$. alexandrinus pairs along the Sicilian coast are not homogeneous, with a sharp unbalance between the southeastern slope of the region and the northern Tyrrhenian and Ionian coasts (Tab. 2). Indeed, along $350 \mathrm{~km}$ of coast from "Portopalo di Capo Passero" (Syracuse), the southernmost tip of Sicily, to Trapani, 132-181 pairs were recorded/estimated, with a KAI (Kilometric Abundance Index, Buckland et al., 1993; Vincent et al., 1991) of 0.37-0.51. On the other hand, only 40-60 pairs were estimated along about 380 $\mathrm{km}$ from the northern coast from Palermo to Messina and south to Catania (excluding the sandy coast of its gulf), with a much lower KAI of 0.11-0.17.

The Sicilian breeding habitats are mainly represented by sandy beaches (59\%), saltpans (16.5\%) and brackish coastal ponds/marshes (14\%) and, to a lesser extent, by rocky coasts (5.7\%) and gravel beaches (4\%), as shown in Fig. 14.

It is clear how the low reproductive success of the species, similar to other Italian regions, is mostly related to a wrong or totally absent sustainable management of the coastline, especially of the beaches, by the municipalities and other public bodies in charge. Alack of regulations and, most of all, of their enforcement, are causing a severe fragmentation and reduction of the suitable nesting habitats. This makes the pressure exerted on these delicate environments unsustainable and incompatible with the reproduction of C. alexandrinus, whose survival is under the continuous harsh test of both naturally occurring threats and, what is worst, uncontrolled anthropogenic activities (Fig. 15).

How can we effectively protect $C$. alexandrinus while increasing its breeding success in Sicily?

The collection of wintering and breeding data ("situation analysis", Hocking et al., 2006) is essential, but needs to be followed by subsequent steps during which the help and support of other professional figures is essential to implement realistic and effective conservation measures. Otherwise, the risk is to fall in the "analysis-paralysis syndrome". This is an inconclusive and ineffective strategy only capable to produce a detailed analysis of the current situation without, however, taking immediate short-term conservation actions (Battisti et al., 2020). 
Tab. 1 - Results of Kentish plover monitoring during the years 2018-19; the UTM squares surveyed and the length of coastline investigated by the surveyors are shown. Threat codes (last column) are shown in order of decreasing importance of impact (after Biondi \& Pietrelli, 2011). / Risultati del monitoraggio del fratino per gli anni 2018-19. Sono indicati i quadranti UTM rilevati e la lunghezza della costa indagata dai rilevatori. I codici di minaccia (ultima colonna) sono mostrati in ordine decrescente in base all'importanza dell'impatto (Biondi \& Pietrelli, 2011). a) habitat transformation and habitat loss / trasformazione e perdita di habitat; b) habitat fragmentation / frammentazione dell'habitat; c) marine and coastal erosion / erosione marina e costiera; d) mechanical cleaning of the beaches / pulizia meccanica delle spiagge; A) leisure activities and generalized anthropic disturbances / attività recreative e disturbo antropico generico; e) sunbathing and trampling / balneazione e calpestio; f) angling / pesca; g) off road vehicles / veicoli fuoristrada; h) dogs and cats / cani e gatti; i) kite surfing / kite surf; L) natural predators / predatori naturali; m) competition with other shorebird species /competizione con alter specie di limicoli; n) vegetation growth / crescita della vegetazione; o) unfavourable water levels / livelli idrici sfavorevoli; p) collection of eggs and chicks / raccolta di uova e pulcini ; q) wetland reclamation / bonifica di zone umide.

\begin{tabular}{|l|c|c|c|c|c|c|c|}
\hline \multirow{2}{*}{ PROVINCE } & \multicolumn{3}{|c|}{ BREEDING } & \multicolumn{3}{c|}{ WINTERING } & MAIN THREATS \\
\hline & No. of pairs & $\mathbf{k m}$ & UTM 10x10 & No. of ind. & km & UTM 10x10 & \\
\hline Trapani & $54-67$ & 70 & 13 & $95-130$ & 15 & 9 & a,A,d,e,f,g,h,i,o \\
\hline Palermo & $15-20$ & 16 & 7 & $15-20$ & 8 & 3 & a,d,A,e,f,g,h,m \\
\hline Messina & $25-40$ & 40 & 7 & $35-50$ & 10 & 2 & A,d,e,f,a,g,m? \\
\hline Catania & $8-13$ & 20 & 3 & $29-36$ & 20 & 3 & a,c,e,A,d,f,h,m \\
\hline Syracuse & $30-40$ & 16 & 10 & $60-140$ & 10 & 10 & a,A,e,c,f,o,m,L? \\
\hline Ragusa & $21-25$ & 25 & 6 & $50-65$ & 20 & 6 & a,A,e,d,f,c,g,i,p,L? \\
\hline Caltanissetta & $30-37$ & 26 & 6 & $35-50$ & 15 & 6 & A,b,c,d,e,g,h \\
\hline Agrigento & $22-45$ & 17 & 12 & $57-72$ & 10 & 7 & A,e,g,h,L,p \\
\hline Total & $\mathbf{2 0 5 - 2 8 7}$ & 230 & 64 & $\mathbf{3 7 6 - 5 6 3}$ & 108 & 46 & \\
\hline
\end{tabular}

Tab. 2 - Comparison of pairs abundance on sandy beaches along the three Sicilian coasts shows a higher presence to the south, along the Mediterranean coast. / Il confronto dell'abbondanza di coppie sulle spiagge sabbiose lungo le tre coste siciliane mostra una maggiore presenza a sud, lungo la costa mediterranea.

\begin{tabular}{|l|l|c|c|c|}
\hline Coast & Involved provinces & Tot. $\mathbf{k m}$ & No. of pairs & Kai \\
\hline North: Tyrrhenian & Palermo, Messina & 380 & 9 & $\mathbf{0 . 0 2}$ \\
\hline East: Ionian & Messina, Catania, Syracuse & 260 & 18 & $\mathbf{0 . 0 7}$ \\
\hline South: Mediterranean & Syracuse, Ragusa, Caltanissetta, Agrigento, Trapani & 350 & 87 & $\mathbf{0 . 2 5}$ \\
\hline
\end{tabular}

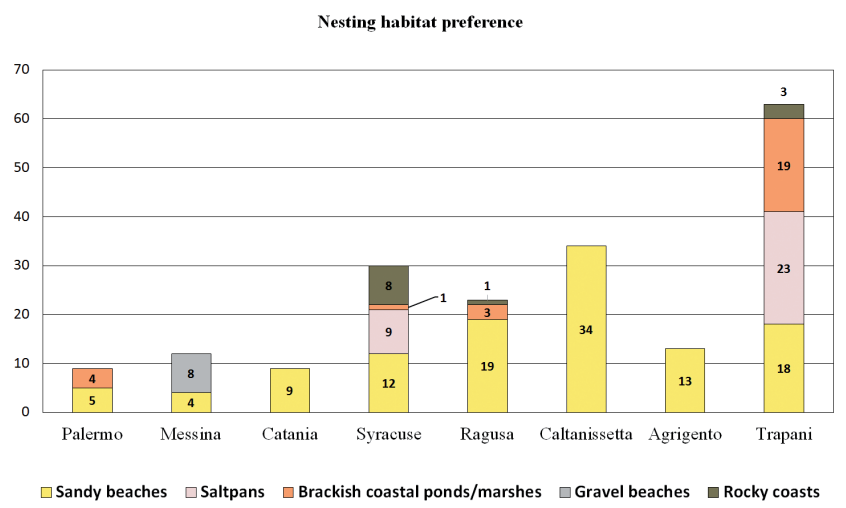

Fig. 14 - Preference of nesting habitat in the 8 Sicilian provinces based on 193 confirmed nests records. / Ambienti di nidificazione preferenziali nelle 8 province siciliane sulla base di 193 record di nidificazione confermati.

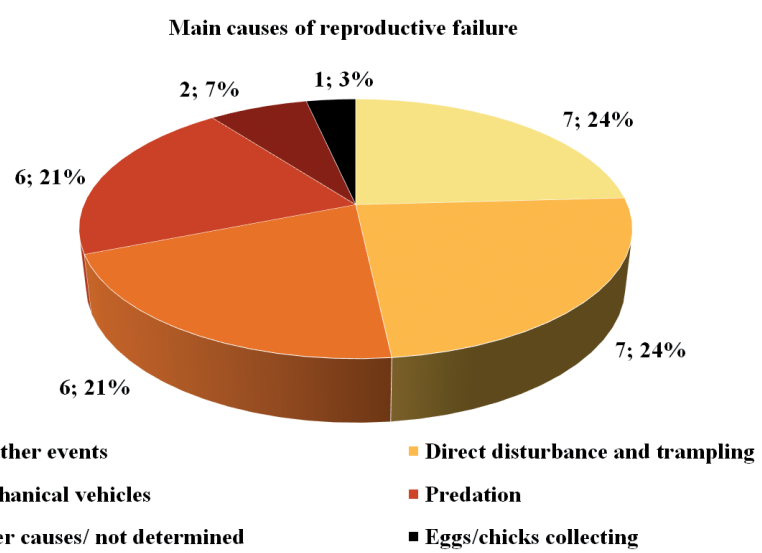

Fig. 15 - Main causes of reproductive failure on 29 observed cases. / Principali cause di fallimento riproduttivo su 29 casi osservati. 
Ornithologists can develop good guidelines for assessing the status of $C$. alexandrinus and other shorebird species, but they also require knowledge of the many "weapons" available in the project management arsenal (Battisti et al., 2020). These include creative brainstorming techniques aimed at obtaining original solutions, communication techniques to approach the public, decision-making skills, evaluation of the costs/benefits balance to select the best conservation options, scenario analysis, stakeholder analysis, outcome monitoring design (Battisti, 2018). Furthermore, both editing and release of strategies require time: the decision-making timing of high-level strategies must adapt to the timing of species phenology and to the local crisis contexts (Battisti et al., 2020).

\section{Conservation Strategies}

Here below, a concise list of conservation strategies and principles suggested to overcome the analysis-paralysis syndrome and to move forward to the actions that might have a truly positive impact:

- information, awareness-raising, collaboration and involvement of the competent public agencies on all administrative levels is essential, following the path of intervention planning and coastal management, especially of bathing facilities and beaches, also with the help of ornithologists and technicians competent in the field of biodiversity conservation. Small and positive initiatives at local level, e.g. converting beaches in "Kentish Plover Friendly Beach", as it has been already done in other Italian regions (De Sanctis et al., 2011), can represent a starting point to replicate involving nearby municipalities and provinces;

- identification and reporting of breeding areas and pairs to the concerned municipalities and to the bodies in charge is a first step that should be followed by placing informative panels at the entrance of the beaches where the species breeds, in order to involve people by giving information about its presence and biology (Antinori et al., 2011). Lifeguards and all the operators involved in beach surveillance and maintenance should be informed and prepared before the start of the bathing season to avoid chick and eggs collection as well as direct disturbing of breeding pairs. Other means of information and communication (local and in situ using flyers, gadgets and by means of public events and the use of social-media) aimed at improving people awareness in a simple and effective way, should be promoted and encouraged (Battisti et al., 2020);

- creation and proper formation of local groups of volunteers, involving citizens coordinated by ornithologists, biologists and other experts, to collect data and monitoring pairs and nests is helpful, but without underestimate the value of monitoring the effects of direct conservation actions (e.g. metal wire nets, nests markers, fencing) on breeding success.

In addition, we would also like to point out some of the most important and effective field conservation actions here suggested:
- fencing and banning access to part of the most important stretches of beach (including those located at bathing facilities), as well as the mouths of watercourses, at least from April to July, must be considered a priority conservation action that brings great benefits to the species (Biondi et al., 2018; Biondi et al., 2020);

- on beaches where the dune system is still preserved, it is strongly recommended to fence at least part of the dune belt with natural material such as wooden poles or reed mats (Tinarelli, 2011) to create buffer zones (Antinori et al., 2011); it is also advisable to build wooden walkways to avoid crossing the dunes when reaching the shoreline;

- the available nesting surfaces should be improved and increased where is possible, mainly inside nature reserves and other protected areas, also by means of artificial shores and islets, considering also a sufficient surface area for the feeding of chicks (Borgo et al., 2018);

- former saltpans and part of active saltpans could be fenced in, to stop threats as fishing, mechanical vehicles and stray dogs and cats. In the active saltpans, water levels should be managed in relation to the nesting period, avoiding flooding of dykes or total emptying of large portions of the saltpan (Tinarelli, 2011);

- vehicles access, including quads and motocross, should be strictly prohibited on every beach, especially near breeding sites;

- every mechanical beach cleaning/grooming action should be strictly regulated applying the current Italian legislation (DGR 1224-08) (Tinarelli, 2011) and avoiding the total removal of vegetal material (Meschini et al., 2011); initiatives organised and promoted by environmental associations in the middle of the breeding season can represent a major source of disturbance for pairs and a threat for eggs and chicks;

- fishing lines and hooks left along the coast represent a threat for many organisms, including plovers such as C. alexandrinus (Battisti et al., 2019) and may lead to traumas, such as abrasions, wounds with subsequent epibiotics infection, starvation, impaired mobility, and consequent heightened risk of predation until, in the worst of cases, to amputation, choking and eventually to death (Chiappone et al., 2005; Criddle et al., 2009; Gregory, 2009).

Due to their chemical composition, the degradation of fishing lines is very slow, which prolongs their persistence (and dangerousness) in the environment over a long time. Therefore, specific periodic cleaning to remove this neglected anthropogenic litter should be planned and applied just before the start of the breeding season, at least along sandy beaches (Battisti et al., 2019). In addition, placing rubbish bins near the entrances to beaches, especially if they are heavily frequented by anglers, could help mitigate this problem.

\section{CONCLUSION}

While the causes limiting the breeding of $C$. alexandrinus on the coast are clearly related to the anthropogenic disturbance that the beaches have been suffering 
over the last three decades, it is not at all clear what factors have caused such a marked decline of the species in other habitats, such as lagoons, saltpans and coastal ponds. In particular, the causes of such a concerning decrease in the "Saline di Trapani and Marsala" are still unclear. In fact, the area has not undergone deep changes in recent years and, thanks to the establishment of two nature reserves ("Riserva Naturale Saline di Trapani" and "Riserva Naturale dello Stagnone di Marsala"), it is now subject to a higher level of protection and a greater limitation of the anthropogenic disturbance than in the past. Furthermore, the hypothesis of the yellow-legged gull Larus michahellis as a predator of eggs and chicks of the Kentish plover did not produce convincing evidence when tested (Doro, 2020). On the other hand, it should be noted that in recent years, it has become customary to pump more seawater into the saltpans in order to have a more abundant harvest. This type of management is significantly reducing the availability of nesting sites for birds along the leeves and is causing flooding of the nests and consequent egg loss, as well documented for Sternula albifrons, Recurvirostra avosetta and Himantopus himantopus (Doro, 2020). Furthermore, the hypothesis of an alteration in the abundance of the detrital arthropod fauna, a staple food item for the Kentish plover, should be evaluated (Surdo \& Matteucci, 2016).

A continuous monitoring of the Sicilian C. alexandrinus population and of the related conservation strategies, as well as a greater involvement of municipalities, competent bodies, associations, local volunteers and managing bodies of nature reserves is highly recommended for the future.

\section{Acknowledgements}

We are deeply indebted to all the people who shared their data, information and personal observations for the success of our joint research effort: Ciro Amata, Giovanni Amato, Salvatore Baglieri, Carlo Cappuzzello, Fabio Cilea, Andrea Corso, Fabio Crisafulli, Piero Ferrandes, Egle Gambino, Elena Grasso, Salvo Grenci, Giovanni La Grua, Alessandro Gurreri, Luca Ilahiane, Gaspare Indelicato, Nino Di Lucia, Loredana Murabito, Nino Patti, Oleana Prato, Giuseppe Rannisi, Deborah Ricciardi, Vincenzo Sciabica, Angelo Scuderi, Domenico Tavormina and Andrea Volpe. We gratefully acknowledge Gianandrea La Porta and Camillo Cusimano for their useful suggestions when making the QGIS maps. A special thanks to the staff of the nature reserve "Saline di Trapani e Paceco" and more specifically to Anna Giordano, Gerardo Cortellaro, Nicola Trapani and Silvana Piacentino. We also thank Luciano Babos (SAGER) and his collaborators that have been involved in the conservation policy; in particular, we are grateful to Giuseppe Mazzotta and Dylan Pelletti for their commitment on nests surveillance and monitoring. We also wish to thank the editor of Natural History Sciences and two anonymous referees for improving a first draft of the manuscript and for providing valuable suggestions.

\section{REFERENCES}

AA.VV., 2008 - Atlante della Biodiversità della Sicilia: Vertebrati terrestri. Studi \& Ricerche, Arpa Sicilia, Palermo, 6.

Antinori F., Mitri M. G., Castelli S. \& Borgo A., 2011 - La tutela delle popolazioni nidificanti di Fratino (Charadrius alexandrinus) sui litorali veneziani (1985-2010). In: Il Fratino. Status, biologia e conservazione di una specie minacciata. Biondi M. \& Pietrelli L. (a cura di). Atti del convegno nazionale, Bracciano (RM), 18 Settembre 2010. Edizioni Belvedere, le scienze, (LT), 13: 21-33.

Baccetti N., Dall'Antonia P., Magagnoli P., Melega L., Serra L., Soldatini C. \& Zenatello M., 2002 - Risultati dei censimenti di uccelli acquatici svernanti in Italia: distribuzione, stima e trend delle popolazioni nel 1991-2000. Biologia e Conservazione della Fauna, 111: 1-235.

Baglieri S., 1972 - Osservazioni di nidificazione del Fratino (Charadrius a. alexandrinus, Linneo) nelle saline di Siracusa. Rivista italiana di Ornitologia, 42: 176-180.

Battisti C., 2018 - Unifying the trans-disciplinary arsenal of project management tools in a single logical framework: Further suggestion for IUCN project cycle development. Journal for Nature Conservation, 41: 63-72. <https://doi.org/10.1016/j.jnc.2017.11.005>

Battisti C., Kroha S., Kozhuharova E., De Michelis S., Fanelli G., Poeta G., Pietrelli L. \& Cerfolli F., 2019 - Fishing lines and fish hooks as neglected marine litter: first data on chemical composition, densities, and biological entrapment from a Mediterranean beach. Environmental Sciences and Pollution Research, 26: 10001007. <https://doi.org/10.1007/s11356-018-3753-9>

Battisti C., Gustin M. \& Polinori A., 2020 - Do the weaknesses and strengths of experts and local volunteers affect the conservation actions focused on nesting plovers? Constructive considerations from the Italian beach front line. Avocetta, 44: 105-111. <https:// doi.org/10.30456/AVO.2020205>

Bibby C. J., Burgess N. D., Hill D. A. \& Mustoe S. H., 2000 - Bird Census Techniques. Second edition. Academic Press, London, UK.

Biondi M. \& Pietrelli L., 2011 - Consistenza, distribuzione e problematiche relative alla presenza del Fratino (Charadrius alexandri$n u$ s) in Italia. In: Il Fratino. Status, biologia e conservazione di una specie minacciata. Biondi M. \& Pietrelli L. (a cura di). Atti del convegno nazionale, Bracciano (RM), 18 Settembre 2010. Edizioni Belvedere, le scienze, (LT), 13: 215-239.

BirdLife International, 2021 - European Red List of Birds. Pubblication Office of the European Union, Luxembourg.

Biondi M., Pietrelli L., Muratore S., Menegoni P., Landucci G., Soprano M. \& Giannerini S., 2018 - Il Fratino Charadrius alexandrinus nella Tenuta Presidenziale di Castelporziano (RM): monitoraggio e conservazione. Gli Uccelli d'Italia, 43: 5-18.

Biondi M., Pietrelli L., Guerrieri G., Corso A. \& Grussu M., 2000 - Il Corriere piccolo, Charadrius dubius nell'Italia centrale e meridionale. Riv. Ital. Orn., Milano, 70 (2): 97-114.

Biondi M., Pietrelli L., Menegoni P. \& Muratore S., 2020 - Il Fratino Charadrius alexandrinus nel Lazio: periodo 2014-2020. Uccelli d'Italia, 45: 116-126.

Borgo A., Carrer S. \& Ragazzi A., 2018 - Primi dati sulla biologia riproduttiva del Fratino Charadrius alexandrinus Linnaeus, 1759 nidificante in strutture morfologiche artificiali della laguna di Venezia. Bollettino del Museo di Storia Naturale di Venezia, 69: 7789.

Brichetti P. \& Fracasso G., 2004 - Ornitologia italiana. Vol. 2. Tetraonidae-Scolopacidae. Alberto Perdisa Editore, Bologna.

Brichetti P. \& Fracasso G., 2018 - Birds of Italy. Vol. 1. Anatidae-Alcidae. Edizioni Belvedere, (LT).

Buckland S. T., Anderson D. R., Burnham K. P., Laake J., 1993 - Distance Sampling: Estimating Abundance of Biological Populations. Chapman \& Hall, London.

Casamento G., Lo Valvo S., Massa B. \& Pasta S., 2004 - Presentazione al volume: Il contributo dei Parchi e delle Riserve naturali alla conservazione della natura in Sicilia. Naturalista siciliano, 28 (1): 3-8.

Chiappone M., Dienes H., Swanson D. W. \& Miller S. L., 2005 - Impacts of lost fishing gear on coral reef sessile invertebrates in the Florida Keys National Marine Sanctuary. Biological Conservation, 121: 221-230. 
Ciaccio A. \& Priolo A., 1997 - Avifauna della foce del Simeto, del lago di Lentini e delle zone umide adiacenti (Sicilia, Italia). Naturalista siciliano, 21: 309-413.

Cilea F. \& Iapichino C., 2011 - Il Fratino (Charadrius alexandrinus) nella riserva orientata Saline di Priolo (sito natura 2000 ITA090013): interazione e disturbo da parte del Cavaliere d'Italia (Himantopus himantopus). In: Il Fratino. Status, biologia e conservazione di una specie minacciata. Biondi M. \& Pietrelli L. (a cura di). Atti del convegno nazionale, Bracciano (RM), 18 Settembre 2010. Edizioni Belvedere, le scienze, (LT), 13: 61-66.

Corso A., 2005 - Avifauna di Sicilia. Società Editrice L'Epops, Palermo.

Criddle K. R., Amos A. F., Carroll P., Coe J. M., Donohue M. J., Harris J. H., Kim K., MacDonald A., Metcalf K., Rieser A. \& Young N. M., 2009 -Tackling marine debris in the $21^{\text {st }}$ century. The National Academies Press, Washington, DC.

De Sanctis A., De Ascentiis A., Felizzi A. \& Stefano Taglioli S., 2011 La protezione dei nidi di Fratino (Charadrius alexandrinus) in Abruzzo: dagli aspetti giuridici e amministrativi all'esperienza di campo per costruire un "kit-salvafratino" In: Il Fratino. Status, biologia e conservazione di una specie minacciata. Biondi M. \& Pietrelli L. (a cura di). Atti del convegno nazionale, Bracciano (RM), 18 Settembre 2010. Edizioni Belvedere, le scienze, (LT), 13: 3540.

Doro A., 2020 - Indagine sull'avifauna acquatica nidificante in un'area campione della R.N.O. delle Saline di Trapani e Paceco con l'uso di fotocamere. Tesi di Laurea. Università di Palermo.

Galasso P., Grimaldi D., Aiello L. \& Galasso G., 2021 - Wintering Shorebird in sandy coasts of Catania's gulf (Sicily, Italy): 20112020. Rivista Italiana di Ornitologia, 91 (1): 27-38. <https://doi. org/10.4081/rio.2021.506>

Gregory M. R., 2009 - Environmental implications of plastic debris in marine settings-entanglement, ingestion, smothering, hangers-on, hitch-hiking and alien invasions. Philosophical Transactions of the Royal Society, 364: 2013-2025.

Gustin M., Nardelli R., Brichetti P., Battistoni A., Rondinini C. \& Teofili C., 2019 - Lista Rossa IUCN degli uccelli nidificanti in Italia. Comitato Italiano IUCN e Ministero dell'Ambiente e della Tutela del Territorio e del Mare, Roma.

Keller V., Herrando S., Vořišek P., Franch M., Kipson M., Milanesi P., Martì D., Anton M., Klvaňová A., Kalyakin M. V., Bauer H.-G. \& Foppen R. P. B., 2020 - European Breeding Bird Atlas 2: Distribution, Abundance and Change. European Bird Census Council \& Lynx Edicions, Barcelona.

Hockings M., Stolton S. \& Leverington F., 2006 - Evaluating Effectiveness: A framework for assessing management effectiveness of protected areas. International Union for Conservation of Nature, Switzerland.

Iapichino C. \& Massa B., 1989 - The Bird of Sicily. Checklist No. 11. British Ornithologists' Union, Tring.

Ientile R., 2001 - L'avifauna acquatica delle saline megaresi (Siracusa, Sicilia). Naturalista siciliano, 25: 63-108.

Ientile R., 2011 - Stato di conservazione e fattori limitanti per la diffusione del Fratino (Charadrius alexandrinus) in Sicilia. In: Il Fratino. Status, biologia e conservazione di una specie minacciata. Biondi M. \& Pietrelli L. (a cura di). Atti del convegno nazionale, Bracciano (RM), 18 Settembre 2010. Edizioni Belvedere, le scien$z e,(\mathrm{LT}), 13:$ 61-66.

Lo Valvo M., Massa B. \& Sarà M., 1993 - Uccelli e paesaggio in Sicilia alle soglie del terzo millennio. Naturalista siciliano, XVII, Suppl. 1993.

Massa B., 1977 - Studio della popolazione di Fratini (Charadrius a. alexandrinus) delle Saline di Trapani. Naturalista siciliano, 1: 1-15.

Massa B. (red.), 1985 - Atlas Faunae Siciliae. Aves. Naturalista siciliano, 9 ( $\mathrm{n}^{\circ}$ speciale).

Massa B., Lo Cascio P., Ientile R., Canale E. D. \& La Mantia T., 2015 Gli Uccelli delle isole circumsiciliane. Naturalista siciliano, 39 (2): 105-373.

Massa B., Ientile R., Aradis A. \& Surdo S., 2021 - One hundred and fifty years of ornithology in Sicily, with an unknown manuscript by Joseph Whitaker. Biodiversity Journal, 12 (1): 27-89. <https://doi. org/10.31396/Biodiv.Jour.2021.12.1.27.89>
Meschini E. \& Frugis S., 1993 - Atlante degli uccelli nidificanti in Italia. Supplemento alle Ricerche di Biologia della Selvaggina, INFS, 20.

Meschini A., Gregg S., Biondi M. \& Pietrelli L., 2011 - La nidificazione del Fratino (Charadrius alexandrinus) e la dinamica delle dune. Ipotesi gestionali e conservazionistiche in un settore costiero laziale. In: Il Fratino. Status, biologia e conservazione di una specie minacciata. Biondi M. \& Pietrelli L. (a cura di). Atti del convegno nazionale, Bracciano (RM), 18 Settembre 2010. Edizioni Belvedere, le scienze, (LT), 13: 49-54.

Moltoni E., 1973 - Gli uccelli fino ad oggi rinvenuti o notati all'isola di Pantelleria (Provincia di Trapani, Sicilia). Rivista italiana di Ornitologia, 43: 173-437.

Pietrelli L. \& Biondi M., 2009 - Il Fratino Charadrius alexandrinus nel Lazio: Status della specie. Alula, XVI (1-2): 485-490.

Peronace V., Cecere J. G., Gustin M. \& Rondonini C., 2012 - Lista rossa degli uccelli nidificanti in Italia. Avocetta, 36: 11-58.

Raffa A., Cirrone F. L. E., Pepi D., Spinella G. \& Zafarana M. A., 2018 A preliminary map of threats to breeding population of Kentish Plover Charadrius alexandrinus in the Gulf of Gela. Atti del LXXIX Congresso Nazionale dell'Unione Zoologica Italiana, Lecce, 25-28 Settembre 2018.

Serra L., Magnani A., Dall'Antonia P. \& Baccetti N., 1997 - Risultati dei censimenti degli uccelli acquatici svernanti in Italia, 1991-1995. Biologia e Conservazione della Fauna, 101. Istituto Nazionale per la Fauna Selvatica.

Surdo S., 2016 - Note sui limicoli svernanti nelle zone umide costiere della Provincia di Trapani. Naturalista siciliano, 40: 33-49.

Surdo S. \& Barbera A., 2016 - Evoluzione della laguna di Tonnarella (Mazara del Vallo, Trapani) e suo attuale valore ornitologico. Naturalista siciliano, 40: 21-32.

Surdo S. \& Matteucci P., 2016 - Indagine comparativa sulla popolazione nidificante di Fratino Charadrius alexandrinus (Aves Charadriiformes) nelle saline della Provincia di Trapani. Naturalista siciliano, 40: 289-299.

Surdo S., La Mantia T. \& D’Amico D., 2017 - Aggiornamento della checklist degli uccelli della Riserva Naturale Orientata Isole dello Stagnone (Sicilia). Naturalista siciliano, 41 (1): 35-52.

Tinarelli R., 2011 - I litorali dell'Emilia-Romagna: da aree marginali a pseudo baluardo della popolazione nidificante di Fratino (Charadrius alexandrinus): 13-20. In: Il Fratino. Status, biologia e conservazione di una specie minacciata. Biondi M. \& Pietrelli L. (a cura di). Atti del convegno nazionale, Bracciano (RM), 18 Settembre 2010. Edizioni Belvedere, le scienze, (LT), 13: 13-20.

Vincent J. P., Gaillard J. M. \& Bideau E., 1991 - Kilometric index as biological indicator for monitoring forest roe deer populations. Acta Theriologica, 36: 315-328.

Zafarana M. A., 2017 - Limicoli costieri (Aves Charadriiformes) nel Golfo di Gela (Sicilia). Naturalista siciliano, 41: 161-182.

Zafarana M. A., Ientile R., Linares A., Messina A. \& Massa B., 2019 Oasi del Simeto: recente trend di sette specie acquatiche. Atti del XX Convegno Italiano di Ornitologia, Napoli, 26-29 Settembre 2019.

Zenatello M., Baccetti N. \& Borghesi F., 2014 - Risultati dei censimenti degli uccelli acquatici svernanti in Italia. Distribuzione, stima e trend delle popolazioni nel 2001-2010. ISPRA, Serie Rapporti, 206/2014. 